\title{
Challenges and Strategies to Enhance Online Remote Teaching and Learning by Tertiary Institution Educators: A Literature Review
}

\author{
Ahmad Farit Mazlan, Maslawati Mohamad*, Aishath Reesha, Rosnani Kassim, Zarina Othman, \\ Saadiah Kummin
}

Universiti Kebangsaan Malaysia (UKM), Selangor, Malaysia

Email: farit.mazlan@gmail.com, *maslawati@ukm.edu.my

How to cite this paper: Mazlan, A. F., Mohamad, M., Reesha, A., Kassim, R., Othman, Z., \& Kummin, S. (2021). Challenges and Strategies to Enhance Online Remote Teaching and Learning by Tertiary Institution Educators: A Literature Review. Creative Education, 12, 718-726. https://doi.org/10.4236/ce.2021.124050

Received: March 4, 2021

Accepted: April 5, 2021

Published: April 8, 2021

Copyright $\odot 2021$ by author(s) and Scientific Research Publishing Inc. This work is licensed under the Creative Commons Attribution International License (CC BY 4.0).

http://creativecommons.org/licenses/by/4.0/

\section{(c) (i) Open Access}

\begin{abstract}
In 2019, Covid-19 has been declared as a global pandemic. Online remote teaching and learning is the most practical solution to continue teaching and learning particularly at tertiary institutions. There is a drastic change from face-to-face teaching and learning to a fully online teaching and learning environment. Tertiary institutions need to ensure that they consolidate the curriculum and adjust it in accordance with online teaching and learning. In accordance with the new normal in teaching and learning, educators must adapt to new and creative strategies to engage students during online remote teaching and learning. This paper is a literature review on 1) the challenges faced by tertiary institution educators in online remote teaching and learning and 2) strategies that they used to carry out their teaching during this Covid-19 outbreak in order to overcome those challenges.
\end{abstract}

\section{Keywords}

Online Remote Teaching and Learning, Tertiary Institution, Educator, Challenges, Strategies, Covid-19

\section{Introduction}

COVID-19 is a disease that is also known as Corona Virus (Gunther et al., 2020). This virus has caused global pandemic as announced by United Nations Educational, Scientific and Cultural Organizations (UNESCO) and affected teaching and learning at schools and tertiary institutions worldwide (UNESCO, 2020). During this pandemic outbreak, online remote teaching and learning has taken place in schools and tertiary institutions. With the pandemic, the education 
landscape has changed, allowing schools and tertiary institutions to explore suitable strategies to ensure students be able to learn effectively. According to Mohmmed, Khidhir, Nazeer and Vijayan (2020), online teaching is the most suitable approach to teaching and learning when students are forced to stay at home to study due to the pandemic. Many educators in tertiary institutions face challenges in online remote teaching and learning. The main objectives of this literature review are to identify the challenges faced by educators serving different tertiary institutions in their teaching and learning during this Movement Control Order (MCO) period and to identify the strategies used to overcome those challenges. This research is a qualitative research. 10 English teachers from each tertiary institution will be interviewed via Focus Group Interview (face to face or via Zoom or Skype applications), and further individual interviews will be carried out via WhatsApp or Telegram applications. This research will involve 6 tertiary institutions namely Universiti Kebangsaan Malaysia, International Islamic University of Malaysia (IIUM), MARA University of Technology, Islamic University of Maldives, University of Riau Indonesia, and Haripur University, Pakistan. The interview responses will be transcribed in verbatim. The data will be analyzed thematically using NVIVO.

\section{Literature Review}

\subsection{Challenges in Online Remote Teaching and Learning}

\subsubsection{Educators and Students' Motivation in Online Learning}

It is undeniable that educators face many challenges in this new norm of online learning. One of the challenges in online teaching and learning is students' motivation towards online teaching and learning. Motivation can be defined as the student's desire to learn something in a learning environment (Brophy, 2005). The students' motivation is derived from the interaction between the educators and their students (Brophy, 2005). According to Ramli et al. (2020), conventional education processes deal with physical interaction and communication of the students in classrooms. During this pandemic outbreak, educators face difficulties in motivating students to participate and stay attentive during online learning. Aside from the difficulties to motivate, they also have difficulty interacting and supervising the students since they are not meeting them face-to-face.

Mardesci (2020) stated that online learning adversely affected students' motivation to learn due to several factors such as teaching method, lack of facilities such as laptop and internet connection as well as interaction process in the online teaching and learning. Without motivation from both parties, students and teachers, it would be difficult for effective online teaching and learning to take place.

\subsubsection{Inadequate Skills in Online Teaching and Learning}

Another challenge faced by educators is lack of relevant skills to carry out online remote teaching and learning. Technological skills are one of the skills that would affect the effectiveness of online teaching and learning (Sulaiman, 2014). 
For example, in order to upload experimental videos on social platforms like YouTube, they need to be resized and compressed to proper resolution for easy viewing and downloading on electronics devices like computers, laptops, and etcetera. Without these knowledge and skills, educators will find it difficult to prepare materials for online teaching and learning (Azlan et al., 2020).

Educators of tertiary institutions are also facing difficulties in adjusting to a teaching paradigm that demands their familiarity to the online education system (DeAlwis \& David, 2020). The effectiveness of an online teaching and learning rely on the skills that both educators and students possess (Oliver, 2001). Without these skills, knowledge and experience, it will be difficult for educators and students to achieve the objectives in online teaching and learning sessions. In summary, with adequate skills, educators would save time and be able to create more interesting activities for online teaching and learning.

Unfamiliarity with available learning platforms in order to effectively utilize them in delivering online lessons seems to be a challenge that educators have to quickly overcome. Adi Badiozaman, Leong and Wong (2020) reported a preliminary study conducted among 136 teachers in Sarawak who took part in a short course to improve educator's practical digital literacy skills offered by the Swinburne University of Technology Sarawak. All the 136 participants had undergone three courses out of the total seven series of training that were being offered. A questionnaire containing close-ended and open-ended items was distributed among the participants to elicit their views about their digital proficiency including their familiarity with online teaching and learning platforms such as Microsoft Teams and Google Classrooms.

Although $91.2 \%$ of the participants claimed to be familiar with Google Classroom, the reverse was reported in the case of Microsoft Teams. $71.4 \%$ of the participants responded that they were very unfamiliar with Microsoft Teams. This finding was further supported by their responses to the open-ended questions where the participants highlighted that they were in dire need of support in terms of digital pedagogy and technological knowledge. This study reveals that in response to the pandemic, many online teaching platforms have been introduced, for examples, the Microsoft Teams and Google Classrooms. These platforms have their own strengths and if utilized appropriately, will enhance online teaching. Unfortunately, educators are still very unfamiliar with some (in this case, the Microsoft Teams) and this will pose a challenge to them in delivering their lessons effectively.

Another study conducted by Mohd Shaharanee et al. (2020) among lecturers of Universiti Utara Malaysia revealed that because of limited knowledge and skills in online teaching, the lecturers cited that they had low confidence in managing tasks related to remote teaching. The study aimed to investigate the readiness of students, lecturers and the institution towards online teaching and learning. Based on a survey questionnaire answered by 1137 lecturers who were teaching during COVID-19 pandemic, it was found that the infrastructure cate- 
gory which contained 4 items namely "I am confident using LMS platform Web 2.0 tools to facilitate student learning", "I am confident to provide feedback timely feedback on assignments", "I am confident to use features in learning management system in order to manage time (e.g., online grading, rubrics, SpeedGrader, Flubaroo)" and "I am confident to use Webex for synchronous meeting" recorded the lowest mean (3.5209) compared to the other categories in the survey which were the course design (3.7978), course communication (3.9384) and time management (3.7441).

Mohd Shaharanee et al. (2020) concluded that online teaching requires different skills compared to face to face teaching, for instance, the ability to give feedback to students' assignments and examinations online within the stipulated time which was usually limited. Similar to Adi Badiozaman, Leong and Wong's (2020) study, this study too concluded that unfamiliarity with the platform subscribed by the university, which was WEBEX, has affected their online teaching skills adversely. The lecturers were found not to be well versed in using all the features in the online platform which has led them to lose confidence.

\subsubsection{Inadequate Infrastructure in Online Remote Teaching and Learning}

Another challenge in online remote teaching and learning is the problem with infrastructure such as stable internet connection and devices. Online teaching and learning require good internet access (Abd Aziz et al. 2020). Access to online courses need to be supported with a complete infrastructure (Oliver 2001). According to Ahmad et al. (2019), inadequate infrastructure such as the stable internet connection affects the low adoption rate on the integration of new technologies in online teaching and learning. In some cases, facilities such as laptop and mobile phones have to be shared among family members. Limited and low internet connections are the main reasons that will hinder effective online teaching and learning for educators and students. Owusu-Fordjour et al. (2020) stated that without adequate support of learning materials andequipment, the Covid-19 outbreak has challenged students to get proper online teaching and learning. It is very important for both educators and students to have consistent internet access.

\subsection{Strategies in Online Remote Teaching and Learning}

The Covid-19 pandemic has forced the education systems around the world to find some alternatives for learning. In tertiary institutions of Malaysia, the Covid-19 has affected and hampered the whole education system. The local government implemented the movement control order to prevent further spread of Covid-19 (Wong, 2020). Due to this unprecedented Covid-19 crisis, face-to-face classrooms are no longer permitted in most countries as a measure to flatten the spread of Covid-19 pandemic (Rahman, 2020). Online teaching and learning have been fully implemented to address students and educators' teaching and learning needs. There are a few strategies that can be implemented in online re- 
mote teaching and learning such as the use of suitable online platform, applying synchronous and asynchronous tools as well as giving feedback to increase students' motivation and participation.

\subsubsection{The Use of Suitable Online Platform}

Online remote teaching and learning have taken place nationwide in order to ensure the proper learning process is continuous. The best solution for the current problem is by integrating online teaching and learning. Educators and educational institutions administrators have taken a variety of strategies to enhance online teaching and learning. One of the strategies to enhance online teaching and learning is by adopting suitable online platform to carry out teaching and learning as the students are scattered geographically (Azlan et al., 2020). The use of videos, television clips, apps and other practical sources of multimedia can also aid in the online learning experience (Pazilah et al., 2019). Tertiary educators could give online tasks and assignments to students without meeting via face to face (Yustina et al., 2020). This resulted in tertiary institutions' educators adopting various online teaching and learning activities using video streaming platforms such as Zoom, Google Meet, YouTube and others (Yaacob \& Saad, 2020). According to Sutarto, Sari and Fathurrochman (2020) in their study in an Indonesian school, educators use applications for instances Whatsapp, Google Classroom and Zoom for online learning during Covid-19 pandemic to ensure the teaching and learning process is continuous. These apps and online platforms are affordable in terms of cost, more user-friendly and manage to attract students' participation in the teaching and learning.

\subsubsection{Asynchronous and Synchronous Communication in Online Remote Teaching and Learning}

The pandemic outbreak transforms the conventional face-to-face teaching and learning process (Mohmmed et al, 2020). Some scholars believe that online learning provides positive effects at tertiary level. According to them, it enhances creative skills of both students and educators even more compared to conventional teaching and learning (Misanchuk \& Anderson, 2001). In a conventional classroom, interaction between educators and students can be done via face-to-face. In online remote teaching and learning environments, the two-way communication could be done both synchronously and asynchronously (Tartavulea et al. 2020).

According to Motiwalla and Tello (2000), synchronous communication tools facilitate real time collaboration between educators and students. This replicates interaction in conventional classroom whereby students and educators are able to interact and give instant feedback to each other (Lim, 2017). The synchronous tools are audio channels, video conferencing, and online chat rooms.

On the other hand, asynchronous communication tools are an added value. The asynchronous tools used by the tertiary educators are board discussions, emails, WhatsApp and Telegram. Learning could take place at anytime and anywhere. Students would have more time to study and reflect on the topics of 
discussion since they could access these tools of learning at anytime (Lim, 2017).

\subsubsection{Giving Feedback to Increase Students' Motivation}

Motivation can influence what students learn, how they learn and when they choose to learn (Schunk and Usher, 2012). While trying to ensure the academic development of the students, it is important not to overlook the psychological and socio-emotional aspects of learning (Korkmaz \& Toraman, 2020). According to Chung et al. (2020), the impact of learner motivation and satisfaction is an undeniable important in an online learning process.

Intrinsic motivation drives the educators to take proper actions or steps towards achieving the desired teaching and learning outcomes (Baber, 2020). In addition, in order to provide better guidance on the course content, educators' feedback may serve as a means of developing rapport between students and instructors in online courses (Frisby et al., 2013). According to Poulos and Mahony (2008), students appreciate clear and direct communication regardless of course modality. Crews and Butterfield (2014) add that online classes that support flexibility, and prompt educators' feedback, resulted in effective online teaching and learning. Prompt instructors' feedback and frequent presence enhance students' motivation to participate in online teaching and learning (Cole et al. 2017).

\section{Conclusion}

Covid-19 pandemic has totally changed the education arena globally. Tertiary institutions are facing challenges due to this sudden outbreak. On the bright side, this pandemic has motivated the educational institutions worldwide to upgrade their teaching approaches and facilities. In this paper, we have highlighted few challenges faced by educators in online teaching and learning such as lack of facilities, poor internet connection, lack of required skills and motivation issues. Hence, it is important for the authorities to address these issues. This paper also highlights strategies that educators could use to enhance online teaching and learning in this pandemic outbreak. The importance of using suitable online platforms, the ability to use effective communication such as asynchronous and synchronous communication tools as well as motivating students by giving feedback are among the strategies stated in this paper.

To conclude, it is vital that the findings of this paper could alert relevant authorities such as tertiary institution administrators, officers serving the Ministry of Higher Education and policy makers. They need to develop a good plan and carry out measures to overcome the challenges to ensure the effectiveness of online remote teaching and learning.

\section{Acknowledgements}

This research was funded by the Faculty of Education's Dana Khas Penyelidikan FPEND Covid-19, Universiti Kebangsaan Malaysia (UKM) under the project code GG-2020-021. The authors would also like to express special thanks to all 
research team members, teachers and pupils, for their assistance and contribution in conducting this paper.

\section{Conflicts of Interest}

The authors declare no conflicts of interest regarding the publication of this paper.

\section{References}

Abd Aziz, N. A., Abd Aziz, N. N., Musa, M. H., Malik, S. A., Khalid, R. M., \& MKom, N. N. S. (2020). Exploring Barriers Contributing towards an Effective Online Learning among Undergraduates' Students Using PLS-SEM. Environment-Behaviour Proceedings Journal, 5, 71-76. https://doi.org/10.21834/ebpj.v5i15.2511

Adi Badiozaman, I. F., Leong, H. J., \& Wong, W. (2020). Embracing Educational Disruption: A Case Study in Making the Shift to a Remote Learning Environment. Journal of Applied Research in Higher Education. https://doi.org/10.1108/JARHE-08-2020-0256

Ahmad, M. K., Mohd Adnan, A. H., Yusof, A. A., Mohd Kamal, M. A., \& Mustafa Kamal, N. N. (2019). Using New Technologies to Teach English in Malaysia-Issues and Challenges. Proceedings of the International Invention, Innovative \& Creative (InIIC) Conference, Series, Melaka, 27 April 2019, 203-207.

Azlan, C. A., Wong, J. H. D., Tan, L. K., Huri, M. S. N. A., Ung, N. M., Pallath, V., Ng, K. H. et al. (2020). Teaching and Learning of Postgraduate Medical Physics Using Internet-Based e-Learning during the COVID-19 Pandemic-A Case Study from Malaysia. Physica Medica, 80, 10-16. https://doi.org/10.1016/i.ejmp.2020.10.002

Baber, H. (2020). Determinants of Students' Perceived Learning Outcome and Satisfaction in Online Learning during the Pandemic of COVID-19. Journal of Education and e-Learning Research, 7, 285-292. https://doi.org/10.20448/journal.509.2020.73.285.292

Brophy, J. (2005). Goal Theorists Should Move On from Performance Goals. Educational Psychologist, 40, 167-176. https://doi.org/10.1207/s15326985ep4003 3

Chung, E., Subramaniam, G., \& Dass, L. C. (2020). Online Learning Readiness among University Students in Malaysia amidst COVID-19. Asian Journal of University Education, 16, 46-58. https://doi.org/10.24191/ajue.v16i2.10294

Cole, A., Anderson, C., Bunton, T., Cherney, M., Fisher, V. C., Featherston, M., \& Allen, M. (2017). Student Predisposition to Instructor Feedback and Perceptions of Teaching Presence Predict Motivation toward Online Courses. Online Learning Journal, 21, 245-262. https://doi.org/10.24059/olj.v21i4.966

Crews, T., \& Butterfield, J. (2014). Data for Flipped Classroom Design: Using Student Feedback to Identify the Best Components from Online and Face-to-Face Classes. Higher Education Studies, 4, 38-47. https://doi.org/10.5539/hes.v4n3p38

DeAlwis, C., \& David, M. K. (2020). Pennywise Rips Your Arms Off, You Still Won't Be Able to Wipe, So Keep Walking: Teaching during COVID-19 Lockdown. Horizon, 2, $145-158$

Frisby, B. N., Limperos, A. M., Record, R. A., Downs, E., \& Kerscmar, S. E. (2013). Students' Perceptions of Social Presence: Rhetorical and Relational Goals across Three Mediated Instructional Designs. MERLOT Journal of Online Learning and Teaching, 9, 468-480.

Gunther, F., Bender, A., Katz, K., Kuchenhoff, H., \& Hohle, M. (2020). Nowcasting the COVID-19 Pandemic in Bavaria. Biometrical Journal. 
https://doi.org/10.1101/2020.06.26.20140210

Korkmaz, G., \& Toraman, Ç. (2020). Are We Ready for the Post-COVID-19 Educational Practice? An Investigation into What Educators Think as to Online Learning. International Journal of Technology in Education and Science (IJTES), 4, 293-309. https://doi.org/10.46328/ijtes.v4i4.110

Lim, F. P. (2017). An Analysis of Synchronous and Asynchronous Communication Tools in e-Learning. Advanced Science and Technology Letters, 143, 230-234. https://doi.org/10.14257/astl.2017.143.46

Mardesci, H. (2020). The Effect of Online Learning on University Students' Learning Motivation. Online Learning, 1, X6.

Misanchuk, M., \& Anderson, T. (2001). Building Community in an Online Learning Environment: Communication, Cooperation and Collaboration.

Mohd Shaharanee, I. N., Abu Bakar, M. S., Nordin, H., Ibrahim, N. M. B. H., Jamil, J. M., \& Ang, J. S. (2020). Assessing Lecturer's Readiness for Online Learning Implementation during COVID-19 Outbreak. Ilkogretim Online-Elementary Education Online, 19, 79-84. http://ilkogretim-online.org

Mohmmed, A. O., Khidhir, B. A., Nazeer, A., \& Vijayan, V. J. (2020). Emergency Remote Teaching during Coronavirus Pandemic: The Current Trend and Future Directive at Middle East College Oman. Innovative Infrastructure Solutions, 5, Article No. 72. https://doi.org/10.1007/s41062-020-00326-7

Motiwalla, L., \& Tello, S. (2000). Distance Learning on the Internet: An Exploratory Study. The Internet and Higher Education, 2, 253-264. https://doi.org/10.1016/S1096-7516(00)00026-9

Oliver, R. (2001). Assuring the Quality of Online Learning in Australian Higher Education. Proceedings of Moving Online II Conference, Gold Coast QLD, n.d., 222-231.

Owusu-Fordjour, C., Koomson, C. K., \& Hanson, D. (2020). The Impact of Covid-19 on Learning-The Perspective of the Ghanaian Student. European Journal of Education Studies, 7, 88-101.

Pazilah, F. N., Hashim, H., \& Yunus, M. M. (2019). Using Technology in ESL Classroom; Highlights and Challenges. Creative Education, 10, 3205-3212.

https://doi.org/10.4236/ce.2019.1012244

Poulos, A., \& Mahony, M. J. (2008). Effectiveness of Feedback: The Students' Perspective. Assessment \& Evaluation in Higher Education, 33, 143-154. https://doi.org/10.1080/02602930601127869

Rahman, D. (2020). A Reckoning for Online Learning in Times of Crisis. The Star.

Ramli, M. F., Majid, M., \& Badyalina, B. (2020). Impeding Factors towards the Effectiveness of Online Learning during Covid-19 Pandemic among Social Sciences Students. International Journal of Learning and Development, 10, 37. https://doi.org/10.5296/ijld.v10i4.17921

Schunk, D. H., \& Usher, E. L. (2012). Social Cognitive Theory and Motivation. In R. M. Ryan (Ed.), The Oxford Handbook of Human Motivation (pp. 13-27). Oxford: Oxford University Press. https://doi.org/10.1093/oxfordhb/9780195399820.013.0002

Sulaiman, F. (2014). Online Learning in Higher Education in Malaysia: A Case Study of Students' Future Expectations. International Journal of Humanities and Social Science, 4, 124-128.

Sutarto, S., Sari, D. P., \& Fathurrochman, I. (2020). Teacher Strategies in Online Learning to Increase Students' Interest in Learning during COVID-19 Pandemic. Jurnal Konseling dan Pendidikan, 8, 129-137. https://doi.org/10.29210/147800 
Tartavulea, C. V., Albu, C. N., Albu, N., Dieaconescu, R. I., \& Petre, S. (2020). Online Teaching Practices and the Effectiveness of the Educational Process in the Wake of the COVID-19 Pandemic. Amfiteatru Economic, 22, 920-936. https://doi.org/10.24818/EA/2020/55/920

UNESCO (2020). Malaysia: Literacy Rate. http://uis.unesco.org/en/country/my

Wong, C. H. (2020). Malaysia: Coronavirus, Political Coup and Lockdown. The Round Table, 109, 1-2. https://doi.org/10.1080/00358533.2020.1758381

Yaacob, Z., \& Saad, N. H. M. (2020). Acceptance of YouTube as a Learning Platform during the Covid-19 Pandemic: The Moderating Effect of Subscription Status. TEM Journal, 9, 1732. https://doi.org/10.18421/TEM94-54

Yustina, Y., Syafii, W., \& Vebrianto, R. (2020). The Effects of Blended Learning and Project-Based Learning on Pre-Service Biology Teachers' Creative Thinking Skills through Online Learning in the Covid-19 Pandemic. Jurnal Pendidikan IPA Indonesia, 9, 408-420. https://doi.org/10.15294/jpii.v9i3.24706 